\title{
BIM plug-in technology for construction waste quantification
}

\section{André Nagalli ${ }^{1}$, , Luna Ollin Steffen de Oliveira ${ }^{1}$, Annelise Nairne Schamne ${ }^{1}$, Brunno Pereira Barros ${ }^{1}$, Hugo Demay Hochleitner ${ }^{1}$ e Charles Jaster de Oliveira ${ }^{2}$}

\author{
${ }^{1}$ Universidade Tecnológica Federal do Paraná. Campus Curitiba. Sede Ecoville. Rua \\ Deputado Heitor de Alencar Furtado, 5000. Curitiba-PR, Brasil (CEP 81280-340). \\ *E-mail: nagalli@utfpr.edu.br. \\ ${ }^{2}$ Universidade Positivo. Rua Prof. Pedro Viriato Parigot de Souza, 5300. Ecoville. \\ Curitiba-PR, Brasil (CEP 81280-330).
}

\begin{abstract}
Current building management standards demand that construction waste management occurs in the planning phase. This paper presents the development of a plug-in as a BIM tool to predict waste generation. As a research strategy, the plug-in was applied to a single-family housing project, the respective construction wastes were predicted in the BIM technology and compared to the literature. Through waste generation indexes, some planning indicators were calculated. The identified wastes were automatically classified, and a management structure was designed. The study showed that the best results are obtained when the construction waste is estimated from Actual Built Volume instead of Apparent Constructed Volume like the traditional models uses. In conclusion, adopting a plug-in do predict construction waste has proved to be advantageous. A specific advantage of the proposed method is that the plug-in user may adopt their waste generation indexes according to the regional and the production team aspects. The adoption of a plugin made the acquisition and processing of data fast and versatile.
\end{abstract}

Keywords: Estimation; Waste prediction; Building information modelling; Construction waste; Demolition waste.

Resumo. Plugin para quantificação de resíduos de construção civil em ambiente BIM. Os padrões atuais de gestão das construções exigem que o planejamento para a gestão dos resíduos de construção ocorra na fase de projeto dos empreendimentos. Este artigo apresenta o desenvolvimento de um plugin a ser utilizado em ambiente BIM para predição da geração de resíduos de construção. Como estratégia de pesquisa, o plugin foi aplicado a um projeto habitacional unifamiliar, os respectivos resíduos de construção foram previstos na tecnologia BIM e comparados à literatura. Por meio de índices de geração de resíduos foram calculados alguns indicadores de planejamento.
Received

Octuber 5, 2021

Accept

December 13, 2021

Released

December 31, 2021

Open access

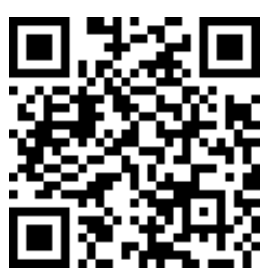

ORCID

(D) 0000-0002-3985-755X André Nagalli

(D) 0000-0002-3624-8708

Luna Ollin Steffen de

Oliveira

(D) 0000-0002-5684-6246

Annelise Nairne

Schamne

D) 0000-0001-7253-8748 Brunno Pereira Barros

ISSN 2359-1412/RBGAS-2021-0130/2021/8/20/20/1605

Rev. Bras. Gest. Amb. Sustent.

http://revista.ecogestaobrasil.net 
Os resíduos identificados foram automaticamente classificados, e uma estrutura de gerenciamento de resíduos foi projetada. 0 estudo mostrou que os melhores resultados são obtidos quando os resíduos de construção são estimados a partir do Volume Real Construído em vez do Volume Construído Aparente, como os modelos tradicionais utilizam. Em conclusão, a adoção de um plug-in para estimativa dos resíduos de construção mostrou-se vantajosa. Uma vantagem específica do método proposto é que o usuário do plugin pode personalizar seus próprios índices de geração de resíduos de acordo com os aspectos regionais e construtivos/produtivos. A adoção de um plugin tornou a aquisição e processamento de dados rápida e versátil.

Palavras-chave: Resíduos de construção e demolição; Estimativa de resíduos; Modelagem da informação da construção.
D) $0000-0003-3831-4411$

Hugo Demay

Hochleitner

(1) 0000-0001-9098-5461

Charles Jaster de

Oliveira

\section{Introduction}

The construction of new buildings brings the challenge of reconciling profitability and sustainability stimulating waste management technics, looking for a leaner construction. This requires not only control during execution but also an investment in planning during the design phase. Building Information Modeling (BIM) has been increasingly used in building planning and management, and its use tends to be bigger and bigger.

Considering the dynamics of calculations of amounts of materials that the BIM allows, it is appropriate to apply it to the calculation of subsidiary planning parameters. Among these parameters, researchers have shown potential for application of this tool to the calculation of amounts of construction waste (Won and Cheng, 2017), of carbon emitted by construction materials (Mousa et al., 2016; Xu et al., 2019), of energy efficiency (Beazley et al., 2017) and of evaluating environmental impacts (Najjar et al., 2017; Shi and $\mathrm{Xu}, 2021$ ). Research (Liu et al., 2015; Won et al., 2016; Abanda et al., 2017) involving BIM and construction waste have evaluated the effects of the design process on the generation of construction waste.

However, the process of evaluation and data management using BIM is usually manual and laborious for secondary parameters as waste. Thus, automate the process of acquiring this information is useful. In this context, this work aims to develop a plug-in to automate the quantification of construction waste through the BIM system in Autodesk Revit software, which is one of the most used BIM software.

\section{Literature review}

\section{Construction and demolition waste}

The construction and demolition waste (CDW) are those from new constructions, restorations, renovations and demolitions of buildings, as well as roads, bridges and any other infrastructure, from all areas of construction (Poon et al., 2001; Cochran et al., 2007; Kofoworola and Gheewala, 2009; Cheng and Ma, 2013). It is observed that, in recent years, the generation of construction waste is significant due to the intensification of construction activities (Guerra et al., 2019).

Because it is a complex process, dependent on variables associated with the productivity of work teams, construction or demolition processes, it is usual to represent the phenomenon of the generation of construction waste through generation rates. 
Scientific research has shown that the generation of CDW is strongly impacted by decisions that occur during work planning or in pre-construction activities (Akinade et al., 2018).

However, the use of waste management software (such as SMARTWaste, NETWaste, DoWT-B) has not been effective, and has not acted in minimizing these (Osmani et al., 2008; Akinade et al., 2018). It is observed in the literature that there is a consensus in stating that designers have an important role in reducing the amount of waste, since they control the building project design. However, minimization and waste management are not usually a priority for designers and architects (Osmani et al., 2008).

Some factors which affect the waste generation are: the organization and cleaning of the construction site, the presence of a quality control system, the professional experience of workers, the acquisition of materials in excessive quantities that generate leftovers, the loss of materials due to theft or loss, the changes in the project or technical specifications and the constructive process losses (Innes, 2004; Ahankoob et al., 2012; Liu et al., 2015). The lack of detailed information about types of materials, volume generated during construction, and disposal makes planning difficult, decreasing the recycled CDW. This creates unnecessary disruption and expenses, which could be avoided by correctly planning and quantifying waste in the design phase (Cheng and Ma, 2013; Abdelhamid, 2014).

The amount of CDW can be estimated based on financial amount of CDW activity (Yost and Halstead, 1996; Cochran et al., 2007; Bergsdal et al., 2007, Masudi et al., 2012); material life cycle (Cochran and Townsend, 2010) or surface area (Lage et al., 2010; Masudi et al., 2012). In the building sites, specifically, the CDW estimation can be based on the built-up area (Jalali, 2007; Cheng and Ma, 2013); physical occupation of space (Lau et al., 2008; Cheng and Ma, 2013) or apparent volume of CDW (Solís-Guzmán et al., 2009). The quantification methods described in the literature have different degrees of limitation, most of them are linked to regional data or require constant updates. The difficulty in compiling CDW generation data results from the lack of cooperation between the entities and agencies responsible for the construction industry and waste disposal of each country/region (Wu et al., 2014).

Guerra et al. (2019) developed algorithms to quantify concrete and drywall residues from a case study. The algorithms developed by the authors are characterized by: i) the use of only linear equations; ii) BIM-based QTO; iii) project purchase records. They can be used for project-level estimates, with the advantage of automating the process. The research results were validated by the authors by means of real data, based on transport control forms. The research demonstrated that the concrete residues varied by $11 \%$ between the predicted and measured (real) quantities, having attributed the fact to several factors (Guerra et al., 2019).

\section{BIM technology as a support tool}

The search for more sustainable buildings is growing in the construction market, not only for adding environmental performance, but also for impacting property acquisition and use of buildings, with relevance to what happens throughout the construction cycle. The search for a more efficient construction management, through the use of Building Information Modeling (BIM), requires that more sustainable buildings include environmental management in this process, considering environmental factors, including construction waste, throughout the entire cycle construction life, in an analysis of the cradle to the grave. Although the most common is the analysis of the issue related to construction, one cannot fail to consider the relevance of waste from demolition or deconstruction processes. Green BIM, so named in the literature, has been extensively studied in the past two years, having presented publications in quantities that increase in exponential behavior (Mueller et al., 2019). 
BIM facilitates alignment of stakeholders and their actions toward higher precision, reliability, and efficiency in the representation and control of material flows in the built environment (Koutamanis, 2020). As the main contributions of BIM, Koutamanis (2020) observed: i) Identification and localization of resources in building elements; ii) estimation of the quality, quantity, and context of resources in a building, and; iii) planning of resource extraction in the framework of regular construction or demolition activities (hence also integration of waste processing in these activities).

The BIM application for environmental purpose is not yet a consensus in the literature (Lu et al., 2017b). The subjectivities intrinsic to the environmental analysis process make it difficult for researchers to parameterize pragmatic environmental solutions. However, several attempts (energy, greenhouse gas emissions, waste) are used to use BIM for environmental and environmental management purposes.

The value derived from complying with the evolving BIM protocol is not uniform across the construction sector (Burt and Purver, 2014). However, BIM is used as a source for conceptual and executive planning, design compatibility and it supports processes and phases throughout the construction lifecycle, allowing the addition of tools to control the generation of waste at the construction site (Eastman et al. 2010; Lu et al., 2017a). BIM technology is especially used to improve detailing, detection of incompatibilities between projects and failures (Hardin and McCool, 2015), visualization and simulation of scenarios (Eastman et al., 2011), as well as improving coordination and communication among different professionals (Krygiel and Nies, 2008). Shi and Xu (2021) recommended full use of Revit to avoid BIM application barriers.

Considering the generation of 3-D digital simulations by BIM, which are automatically updated when the project is changed, there is a powerful instrument for acquiring data and information that is used to manage project costs, executive project monitoring, volumes of materials, schedule, but which can be taken as a basis for the management and estimation of CDW (Akinade et al., 2018; Xu et al., 2019).

In the literature, several BIM applications have been observed in recent years to simulate the energy performance of buildings, to the analysis of lighting / sunlight and even to the question of CDW. Tools in a BIM environment have been proposed in the literature to incorporate environmental sustainability aspects to be assessed throughout the building's use cycle (Lu et al., 2017b). Although the potential for using the BIM environment for CDW management is documented in the literature, there are still no tools capable of satisfactorily resolving the issue (Akinade et al., 2018).

Authors such as Lu et al. (2017a) and Cheng and Ma (2013) sought to use BIM concepts to estimate the volume of waste generated in construction, applying them specifically to the design phase. The use of BIM in the CDW quantification allows more flexibility and autonomy for the constructors, allowing each project to have a specific estimate according to the materials that will be effectively used (Cheng and Ma, 2013). It also allows the inclusion of arguments for each of the materials or objects, allowing specifying, in the design phase, the waste generation index of each one of the enterprise's components. This process is a cooperative virtual arrangement that brings together professionals from different disciplines, ensuring that the aggregate knowledge of each is integrated into a single data source (Eastman et al., 2011).

Most of the tools that integrate the BIM technology have resources that allow adaptation according to the customer's needs. One of these features is the "plug-in", which improves the productivity and efficiency of the user, making their work more competitive in the market, as described by Davis and Peters (2013), Ma et al. (2016) and Bueno and Fabricio (2018). The goal in developing plug-ins is to extend the functionality of the existing BIM software products, as approached by Bilal et al. (2016), to incorporate versatile and complete building waste prediction and minimization tools. 
By enabling BIM to extract data on construction materials, it is possible to accurately predict types and quantities of CDWs. In this way, the implementation of BIM can assist in greater environmental performance of buildings (Mueller et al., 2019). In this research, BIM technology is used as a three-dimensional perspective of interactive and collaborative real-time communication, with the potential to assist project participants in minimizing CDW at all stages of the construction lifecycle, improving the constructive performance (Sacks et al., 2010; Liu et al., 2011).

\section{Research method}

\section{Architectural parameters}

Through a case study of a single-family housing unit, it was developed a plug-in for the automation of acquiring and compiling data from construction waste. The research began with the implementation of the project of the single-family housing unit in program Autodesk Revit@. The characteristics of this housing unit are presented in Table 1 . The authors proposed the layout of the rooms, to reflect the reality of a standard Brazilian housing.

Table 1. Description of room areas.

\begin{tabular}{|l|c|}
\hline Room & Area $\mathbf{~}^{\mathbf{2}} \mathbf{~}$ \\
\hline Living room & 12.09 \\
\hline Kitchen & 3.91 \\
\hline Bathroom & 2.42 \\
\hline Bedroom 1 & 8.66 \\
\hline Bedroom 2 & 7.36 \\
\hline Laundry service & 4.47 \\
\hline Balcony & 3.57 \\
\hline Internal area & $\mathbf{4 1 . 4 7}$ \\
\hline Total built area & $\mathbf{4 9 . 5 1}$ \\
\hline
\end{tabular}

The architectural design included walls of 20 and $15 \mathrm{~cm}$ in width, being respectively external and internal closures. The final wall thickness includes the width of the masonry, finish and coatings. The doors and windows were provided with standardized dimensions. The roof was considered with ceramic tile and ceiling lining with a thickness of $2 \mathrm{~cm}$. The model took shape with the structural design of reinforced concrete, in which the column and beams were executed with stirrups every $15 \mathrm{~cm}$ and rebar ranging from $4.2 \mathrm{~mm}$ to $10 \mathrm{~mm}$ in diameter. The foundation was made of piles in conjunction with the strap footing and the concrete slab was executed with steel mesh.

\section{BIM tool creation}

From the projects detailed by the Autodesk Revit@ the plug-in was applied, performing a study on the generation of solid waste in the modelling residence. The quantification of materials and the modelling were performed in Revit $\circledast$ that allows the entry of parameters into different objects and materials and the use of applications such as Dynamo ${ }^{\circledR}$ and extensions such as Excel ${ }^{\circledR}$.

The construction of the BIM tool started with Dynamo®, in which was used to create a visual programming interface to customize your workflow to make it easier to analyze solutions. Visual Studio® program was applied to insert the plug-in at BIM with a 
new Menu created with specific buttons for each project element. These buttons allow inserting parameters and making necessary calculations from the amount of materials obtained through Autodesk Revit ${ }^{\circledR}$. Excel ${ }^{\circledR}$ complements BIM's functionality by handling the parameterized data obtained from Autodesk Revit ${ }^{\circledR}$ and the created plug-in from Visual Studio®. The data provided by the plug-in is transmitted to Excel $®$ through the Dynamo® application and has the function of refining these processed data, creating graphs and tables.

\section{Plug-in development}

With the creation of the plug-in, it is possible to compile the information provided by the 3D model of the residence and to perform simple equations. Using the C\# (Sharp) language, it was created a parameter called Waste Generation Index (WGI) to be assigned to each element of the project and result in the quantity of material waste generated and the total volume of such waste. By creating an Addin file, developed from the "solution manager" tool, you can start running the plug-in. A new menu, created through Visual Studio $\AA$, was insert in Revit ${ }^{\circledR}$ buttons allow to insert WGI parameters into each project element. The Figure 1 shows how the process of extracting data works.

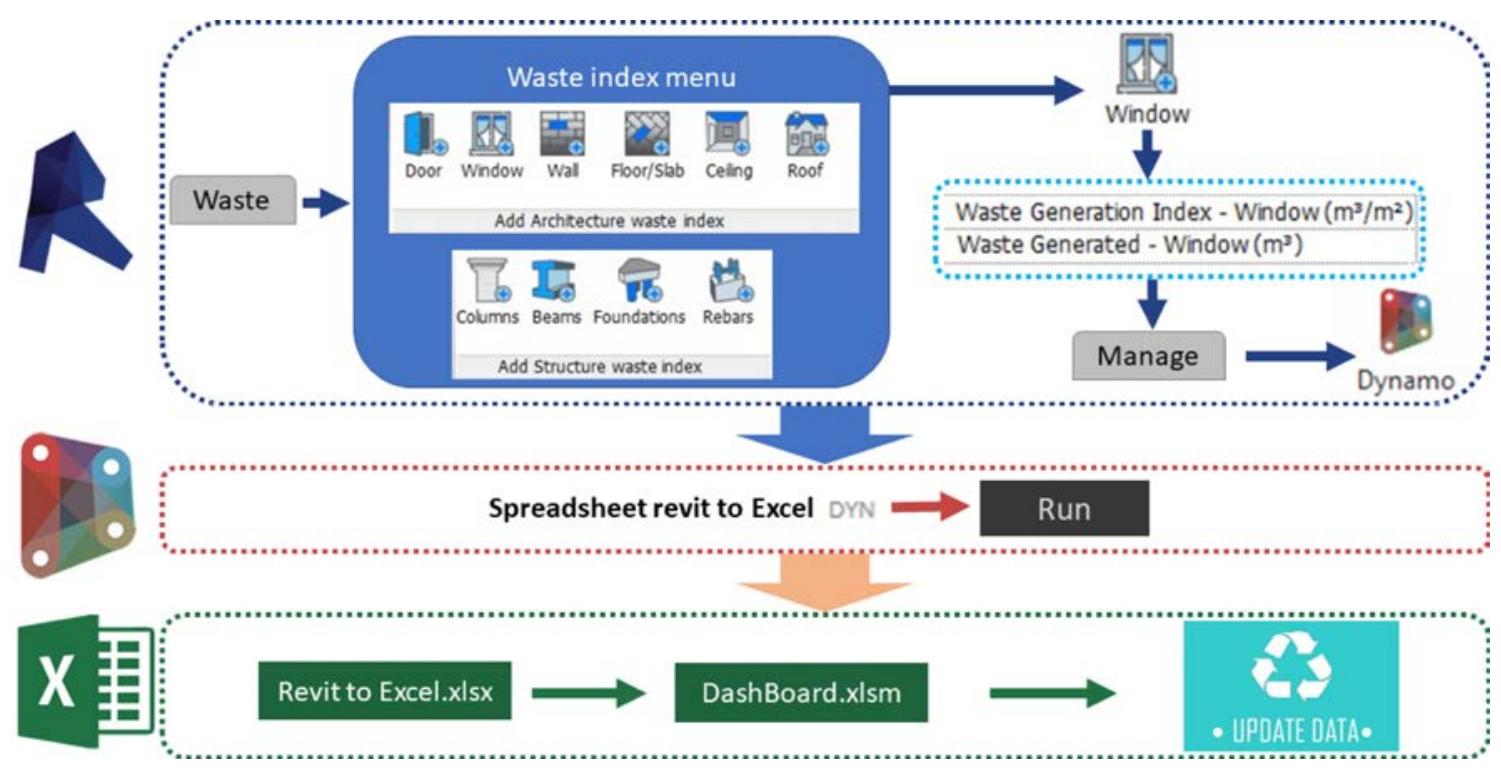

Figure 1. Directional flow of construction waste and its extraction process, archiving and processing of data. Font: The authors

As a plug-in validation strategy, it was used the WGI values proposed by Solís-Guzmán et al. (2009) and the results of waste amount were compared. This model is based on the Apparent Constructed Volume (VAC), while in BIM the calculation basis is the Actual Built Volume (VRC).

With the elements already separated and their respective WGI's inserted a database was created with Dynamo®. The workflow automatically appears in spreadsheets in $\operatorname{Excel}{ }^{\circledR}$.

Some columns can be added from these data to transform the quantitative results into standard units $\left(\mathrm{m}^{2}, \mathrm{~m}^{3}, \mathrm{~kg}\right)$ for use in waste management processes. Some information is relevant in volume, others in bulk, so material density information may be 
required to calculate the weight of the material. The additional columns have equations to obtain the information related to the expected results and data for carrying out unit transformations. In the column related to the amount calculation of waste is used Equation (1).

$$
W_{D i}=Q_{D i} \cdot L_{D i}
$$

In Equation (1) the generated waste (WDi) is equal to the multiplication between the amount of material of an element (QDi) by the residue generation index (LDi). For the calculation of the number of trucks or buckets are used Equations 2 and 3, where VTinert is the volume of total inert waste $\left(\mathrm{m}^{3}\right)$; VTn-inert is the total volume of non-inert waste $\left(\mathrm{m}^{3}\right)$; Vtruck is the volumetric capacity of the truck $\left(\mathrm{m}^{3}\right)$.

$$
\begin{gathered}
N_{\text {inert }}=\frac{V T_{\text {inert }}}{V_{\text {truck }}} \\
N_{\text {n-inert }}=\frac{V T_{\text {-inert }}}{V_{\text {truck }}}
\end{gathered}
$$

\section{Results and discussions} Figure 2.

All the steps described resulted in the BIM interface, within Revit®, according to

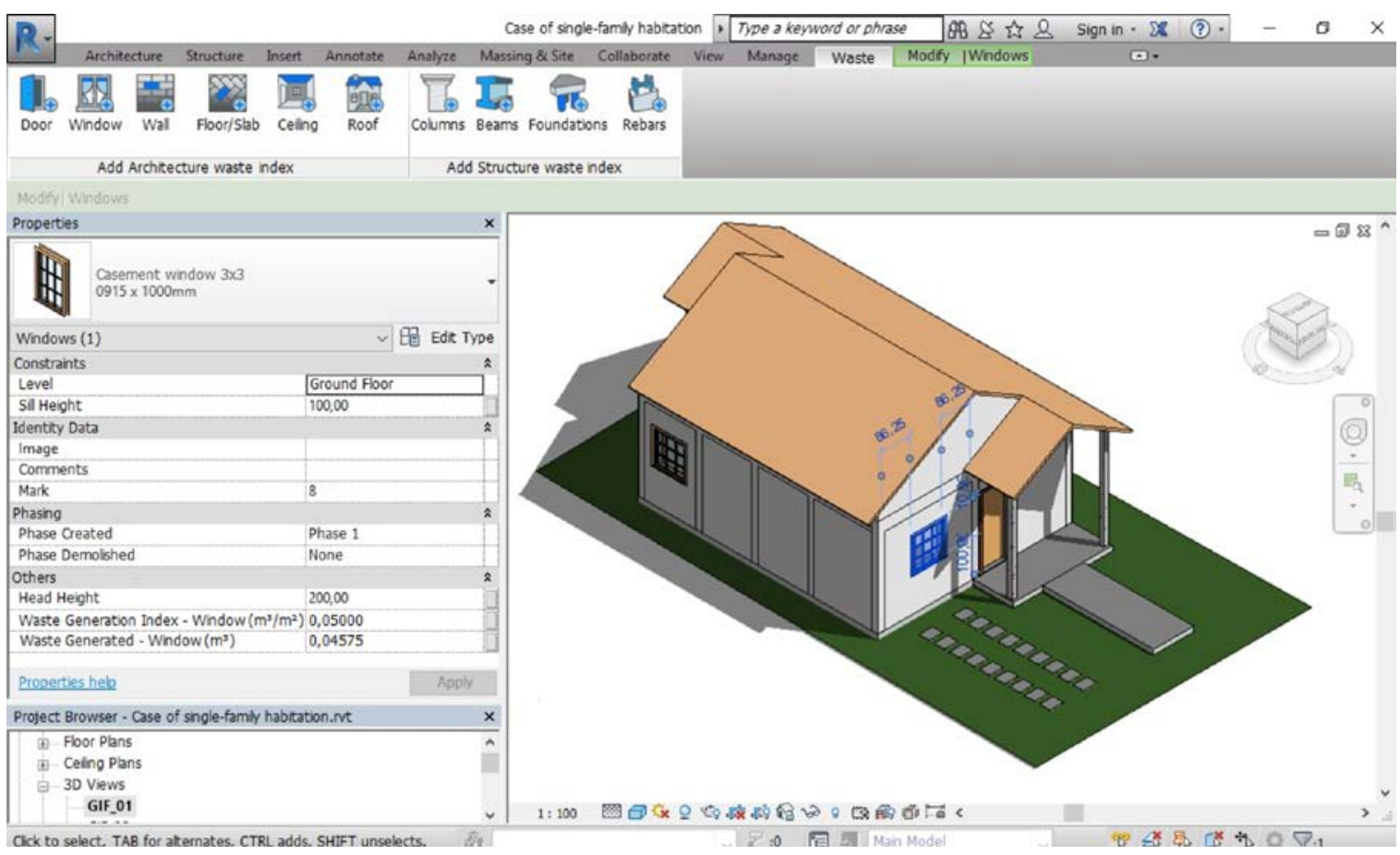

Figure 2. Example application plug-in in Revit $®$ interface on the case study, showing the new commands entered (new tab and buttons of calculations and updates of indicators). 
In the plug-in, the WGI parameters were entered through the "Waste" menu. The "Waste Generated" value was calculated by running Dynamo®, which is accessed through the "Management" menu. The results were exported to Excel® containing each element in a different spreadsheet, with the category, type, unit of measure, WGI and the waste generated by each element. After this process, a final spreadsheet was created through the plug-in with refined data, as shown in Figure 3.

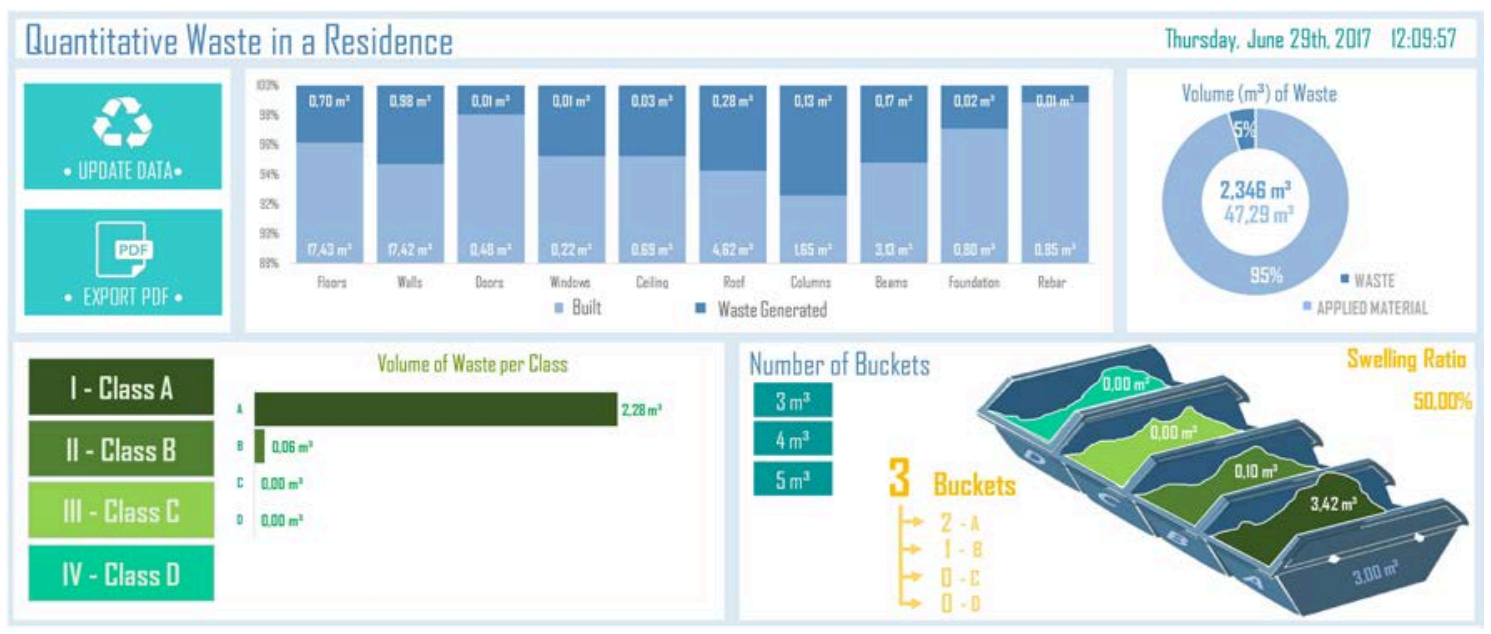

Figure 3. Graphic result of applying the plug-in to the case study, showing the quantitative indicators calculated, structure and its graphical interface collection.

\section{Analysis of BIM results}

Figure 4 shows the amounts of waste calculated from the plug-in run. It is noted that the generation of waste does not have proportionally relation to the amount of construction materials associated with each element of the project (doors, windows, etc.), since the rates of waste generation are specific to each element. Thus, it can be affirmed that using different WGI turns possible to represent the intrinsic aspects of waste generation to each project element, singularizing the waste generation itself and increasing predictive accuracy. This aspect is an advantage over conventional methods of predicting waste from general characteristics of the enterprises, such as the models of Nagalli and Carvalho (2018) and Kern et al. (2015), among others. According to Figure 4, the residence walls are those that generate a greater volume of waste, but the roof and columns generate a greater percentage of waste.

The results show that the total volume of construction materials corresponds to $45.63 \mathrm{~m}^{3}$ while the total volume of waste generated corresponds to $2.31 \mathrm{~m}^{3}$, approximately $5 \%$ of all material used in construction. The walls generated a volume of $0.98 \mathrm{~m}^{3}$, representing the largest amount of waste generated, while doors and windows represent the smallest quantities of waste, with $0.0096 \mathrm{~m}^{3}$ and $0.0112 \mathrm{~m}^{3}$, respectively. Thus, two buckets of $3 \mathrm{~m}^{3}$ or one bucket of $4 \mathrm{~m}^{3}$ for concrete and ceramic waste and a $3 \mathrm{~m}^{3}$ bucket for waste wood, gypsum and steel is required from the plug-in calculation. The plug-in's visual interface enables the user to identify the results calculated for the management indicators. 


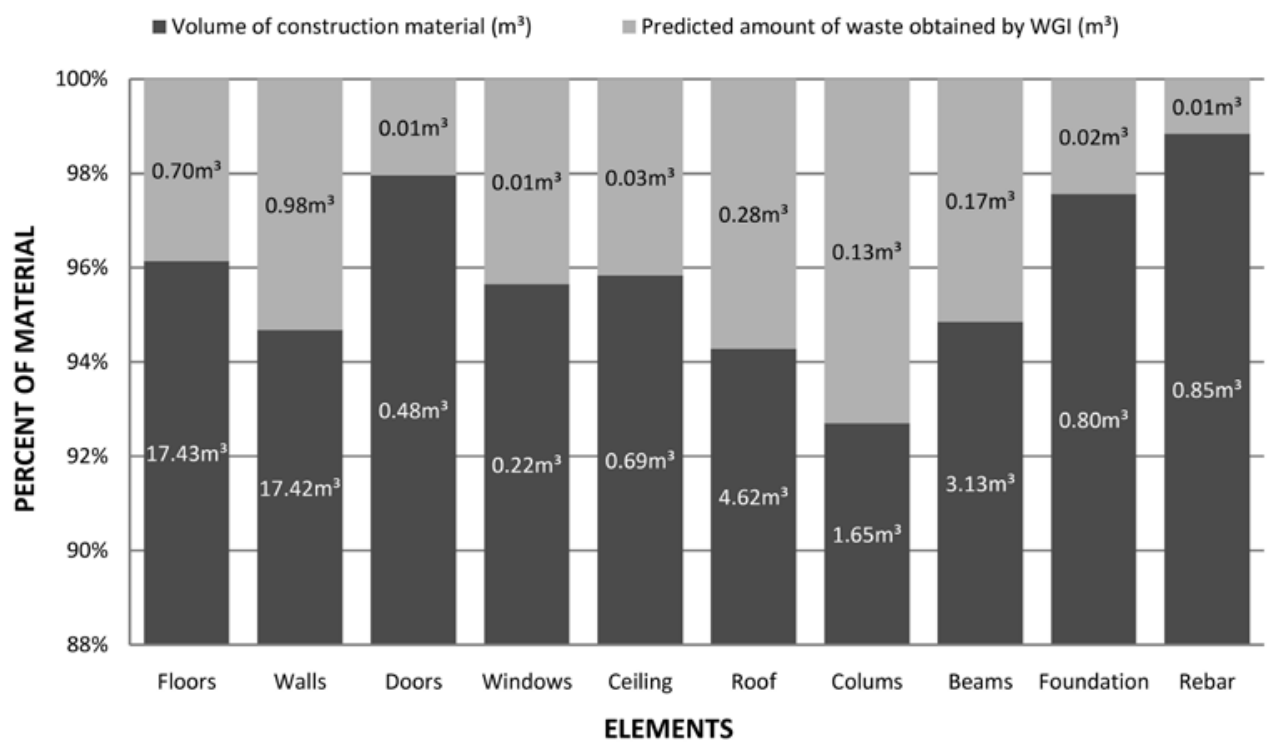

Figure 4. Results calculated by the plug-in, showing the correlation between the planned amount of construction material and the quantities of waste grouped by elements of construction.

The total volume of waste generated was calculated as $2.34 \mathrm{~m}^{3}$ in a residence with a Gross Floor Area (GFA) of $49.51 \mathrm{~m}^{2}$, resulting in an average generation of waste of $0.047 \mathrm{~m}^{3} \cdot \mathrm{m}^{-2}$. According to Pinto (2004), CDW weights on average $1,300 \mathrm{~kg} \cdot \mathrm{m}^{-3}$. Using this density and the average generation of waste, it is possible to convert the waste amount calculated in $61.1 \mathrm{~kg} . \mathrm{m}^{-2}$. Comparing this result with the rate of waste generation cited by Novaes and Mourão (2008), from 100 to $300 \mathrm{~kg} . \mathrm{m}^{-2}$, it appears that the volume of waste per area is below the Brazilian average. However, according to Nagalli et al. (2013), the volume of waste generation per meter square in Brazilian construction is in average 0.051 $\mathrm{m}^{3} \cdot \mathrm{m}^{-2}$, which is compatible with the obtained results $\left(0.047 \mathrm{~m}^{3} \cdot \mathrm{m}^{-2}\right)$. The resulting graph (Figure 3) from plug-in displays the percentage amounts of inert and non-inert waste. This kind of classification is an important cost indicator of final disposal of waste, helping the management process.

The fact that the predicted values of waste have been shown to be compatible with the literature show that it is possible to use waste generation indicators applied to design elements to the detriment of global models of waste generation, such as those presented by Kern et al. (2015) and Nagalli and Carvalho (2018). This aspect validates the use of BIM for the quantitative management of waste, with potential for application of the other utilities and dimensions of the platform.

\section{Plug-in Validation}

For the validation of the plug-in, it was used the model proposed by Solís-Guzmán (2009) in which the apparent volume constructed (Equation 4) is calculated based on the consumption of materials per square meter of built area, multiplied by a CCi factor in meter cubic per standard unit.

$$
\operatorname{VAC}\left(\mathrm{m}^{3} / \mathrm{m}^{2}\right)=Q\left(u n / m^{2}\right) \cdot C C_{i}\left(m^{3} / u n\right)
$$


In Equation (4), VAC corresponds to Apparent Constructed Volume $\left(\mathrm{m}^{3}\right), \mathrm{Q}$ to the amount of material per unit of area $\left(\mathrm{m}^{3} / \mathrm{m}^{2}\right)$ and $\mathrm{CCi}$ to the volume of construction material $\left(\mathrm{m}^{3}\right)$.

The WGI taken from the model of Solís-Guzmán et al. (2009) were applied in BIM model to be possible the comparison of the waste volumes generated as presented in Table 2.

Table 2. Comparison between results of waste quantification through BIM and Solís-Guzmán et al. (2009) models.

\begin{tabular}{|c|c|c|c|c|c|}
\hline \multirow[b]{2}{*}{ Element } & \multicolumn{2}{|c|}{ Plug-in results } & \multicolumn{2}{|c|}{ Solís-Guzmán et al. (2009) } & \multirow[b]{2}{*}{$\begin{array}{l}\text { Gap } \\
(\%)\end{array}$} \\
\hline & $\begin{array}{c}\text { Total } \\
\text { constructed } \\
\text { volume }\left(\mathrm{m}^{3}\right)\end{array}$ & $\begin{array}{c}\text { Waste } \\
\text { generation } \\
\left(\mathrm{m}^{3}\right)\end{array}$ & $\begin{array}{c}\text { Total Material } \\
\text { Consumption } \\
\left(\mathrm{m}^{3}\right)\end{array}$ & $\begin{array}{c}\text { Waste } \\
\text { Generation } \\
\left(\mathrm{m}^{3}\right)\end{array}$ & \\
\hline Paving & 17.43 & 0.70 & 15.64 & 0.620 & 12 \\
\hline Walls & 17.42 & 0.98 & 11.93 & 0.660 & 32 \\
\hline Doors & 0.48 & 0.01 & 0.37 & 0.007 & 26 \\
\hline Windows & 0.22 & 0.01 & 0.06 & 0.003 & 68 \\
\hline Lining & 0.69 & 0.03 & 0.22 & 0.011 & 63 \\
\hline Roofing & 4.62 & 0.28 & 2.29 & 0.140 & 50 \\
\hline Reinforcement & $6,631.0 \mathrm{~kg}$ & $75.5 \mathrm{~kg}$ & $489.3 \mathrm{~kg}$ & $0.003 \mathrm{~kg}$ & $>100$ \\
\hline Concrete structures & 4.78 & 0.30 & 1.48 & 0.069 & 77 \\
\hline
\end{tabular}

Considering only the rubble waste, the waste generation was $0.0268 \mathrm{~m}^{3} . \mathrm{m}^{-2}$ for the Sólis-Guzmán' model and $0.047 \mathrm{~m}^{3} \cdot \mathrm{m}^{-2}$ for the BIM model. Comparing the results, it is observed that the quantification of the waste is influenced by the quantification approach (material consumption or objects volumes). The WGI was maintained the same in both methods, but the amount of materials consumed diverges due to the regional factors, evidenced by the way of quantification of the building materials. Despite the difference, the value approached $0.051 \mathrm{~m}^{3} \cdot \mathrm{m}^{-2}$, a result found by Nagalli et al. (2013) whose results were obtained through field surveys in Brazil.

The development of a plug-in for the quantification of residues in BIM proved to be a useful instrument. Streamlined the process of calculating the amount of waste and allows recalculation in case of possible changes in the project, without the need to refeed parameters in the quantification model. In this way, the influence of project characteristics and modulation and the construction company level of technological development should be incorporated into the waste quantification process (through the adequacy of the WGI). It is evidenced as limitation of the quality of the predictive model the accuracy of the rates of waste generation (WGI) established by the user for each project element. Considering that the trend in this research branch is the development of indicators of waste generation from big data, there is great potential for integration of solid waste management with BIM.

\section{Conclusions}

Building Information Modeling technology has proved to be advantageous to predict the construction waste. The use of Dynamo® and Visual Basic $\AA$ for the development of the waste quantification plug-in, in Autodesk Revit $\AA$, made the acquisition and processing of data fast and versatile. The developed tool allow that designers customize some factors that influences the waste generation. From this, it is possible to adapt the prediction model to the specific work characteristics, as team productivity and 
construction processes. It is also possible to use the developed tool to manage or predict demolition wastes. Additionally, the proposed computational routines made it possible to scale the number of trucks and containers required for the construction site's management.

The application of the developed tool to the project of a single-family housing shows that the results are compatible with the literature, based on Solís-Guzmán (2009) method. In addition, the plug-in presents as the main advantage the speed and dynamic of calculations, making the process of waste quantification adaptable to different construction processes or building materials. The user interaction with the plug-in proved to be suitable and facilitated by the user-friendly interface and illustrative tasks buttons.

It is important to point out that the results obtained are conditioned by the accuracy of the waste generation index applied in the plug-in. Accordingly, the designer needs to use indexes that are compatible with regional characteristics and production aspects, since the calculation routine proposed by the plug-in considers the actual amount of material used in the construction. In this way, the generation of waste used in BIM model differs from those measured in the field, on empirical experiments, which considers the volume of waste per built area. The best results are obtained when the construction waste is estimated from Actual Built Volume instead of Apparent Constructed Volume.

In these terms, this research demonstrated the potential that tools applied to BIM environments are important in construction management. Significant progress could be achieved in the future with the development of specific waste generation indicators for each project element. It is envisaged that future research may discuss the impacts caused by the adoption of waste generation rates on construction elements rather than the general characteristics of the works in predicting the total amount of waste generated in a work, concluding on the best option. Waste management, as demonstrated, becomes more integrated into one of these interfaces that BIM makes it possible to reconcile and integrate. More efficient management is achieved, and the consolidation of BIM in construction sites shows a need.

\section{Conflict of interests}

The authors declare that they have no conflict of interests.

\section{References}

Abanda, F. H.; Tah, J. H. M.; Cheung, F. K. T. BIM in off-site manufacturing for buildings. $\begin{array}{lllll}\text { Journal of Building } & \text { Engineering, } & \text { v. 14, }\end{array}$ https://doi.org/10.1016/j.jobe.2017.10.002

Abdelhamid, M. S. Assessment of different construction and demolition waste management approaches. HBRC Journal, v. 10, no. 3, p. 317-326, 2014. https://doi.org/10.1016/j.hbrcj.2014.01.003

Ahankoob, A.; Khoshnava, S. M.; Rostami, R.; Preece, C. BIM perspectives on construction waste reduction. Proceeding of the Conference of Management in Construction Research Association (MiCRA), UTM RAZAK School of Engineering and Advanced Technology, p. 195-199, 2012.

Akinade, O. O.; Oyedele, L. O.; Ajayi, S. O.; Bilal, M.; Alaka, H. A.; Owolabi, H. A.; Arawomo, 0. O. Designing out construction waste using BIM technology: Stakeholders' expectations for industry deployment. Journal of Cleaner Production, v. 180, p. 375-385, 2018. https://doi.org/10.1016/j.jclepro.2018.01.022 
Beazley, S.; Heffernan, E.; Mccarthy, T. J. Enhancing energy efficiency in residential buildings through the use of BIM: The case for embedding parameters during design. Energy Procedia, v. 121, p. 57-64, 2017. https://doi.org/10.1016/j.egypro.2017.07.479

Bergsdal, H.; Bohne, R. A.; Brattebø, H. Projection of construction and demolition waste in Norway. Journal of Industrial Ecology, v.11, n. 3, p. 27-39, 2007. https://doi.org/10.1162/jiec.2007.1149

Bilal, M.; Oyedele, L. O.; Qadir, J.; Munir, K.; Akinade, O. O.; Ajayi, S.O.; Owolabi, H. A. Analysis of critical features and evaluation of BIM software: Towards a plug-in for construction waste minimization using big data. International Journal of Sustainable Building Technology and Urban Development, v. 6, n. 4, p. 211-228, 2016. https://doi.org/10.1080/2093761X.2015.1116415

Bueno, C.; Fabricio, M. M. Comparative analysis between a complete LCA study and results from a BIM-LCA plug-in. Automation in Construction, v. 90, p. 188-200, 2018.

Burt, J.; Purver, K. Building information modelling for small-scale residential projects. Management, Procurement and Law, v. 167, no. 3, p.134-140, 2014. https://doi.org/10.1680/mpal.13.00019

Cheng, J. C.; Ma, L. Y. A BIM-based system for demolition and renovation waste estimation and planning. Waste Management, v. 33, no. 6, p.1539-1551, 2013. https://doi.org/10.1016/j.wasman.2013.01.001

Ma, Y. P.; Lin, M. C.; Hsu, C. C. Enhance architectural heritage conservation using BIM technology. In: Chien, S.; Choo, S.; Schnabel, M. A.; Nakapan, W.; Kim, M. J.; Roudavski, S. (Eds.). Living systems and micro-utopias: Towards continuous designing, proceedings of the 21st International Conference of the Association for Computer-Aided Architectural Design Research in Asia. Hong Kong: CAADRIA, 2016. p. 477-486.

Cochran, K.; Townsend, T., Reinhart, D.; Heck, H. Estimation of regional building-related C\&D debris generation and composition: Case study for Florida, US. Waste Management, v. 27, no. 7, p. 921-931, 2007. https://doi.org/10.1016/j.wasman.2006.03.023

Cochran, K. M.; Townsend, T. G. Estimating construction and demolition debris generation using a materials flow analysis approach. Waste Management, v. 30, no. 11, p. 2247-2254, 2010. https://doi.org/10.1016/j.wasman.2010.04.008

Davis, D.; Peters, B. Design ecosystems: Customising the architectural design environment with software plug-ins. Architectural Design, v. 83, no. 2, p.124-131, 2013. https://doi.org/10.1002/ad.1567

Eastman, C.; Teicholz, P.; Sacks, R.; Liston, K. BIM handbook: A guide to building information modeling for owners, managers, designers, engineers and contractors. Hoboken, New Jersey: John Wiley \& Sons, 2011.

Guerra, B. C.; Bakchan, A.; Leite, F.; Faust, K. M. BIM-based automated construction waste estimation algorithms: The case of concrete and drywall waste streams. Waste Management, v. 87, p. 825-832, 2019. https://doi.org/10.1016/j.wasman.2019.03.010

Hardin, B.; McCool, D. BIM and construction management: Proven tools, methods, and workflows. Indianapolis, Indiana: John Wiley \& Sons, 2015.

Innes, S. Developing tools for designing out waste pre-site and on-site. Proceedings of Minimising Construction Waste Conference: Developing Resource Efficiency and Waste Minimisation in Design and Construction, New Civil Engineer, London, 2004. 
Jalali, S. Quantification of construction waste amount. International Technical Conference of Waste, v. 6, p. 1-12, 2007.

Kern, A. P.; Dias, M. F.; Kulakowski, M. P.; Gomes, L. P. Waste generated in high-rise buildings construction: A quantification model based on statistical multiple regression. Waste Management, v. 39, p. 35-44, 2015. https://doi.org/10.1016/j.wasman. 2015.01.043

Kofoworola, O. F.; Gheewala, S. H. Estimation of construction waste generation and management in Thailand. Waste Management, v. 29, no. 2, p.731-738, 2009. https://doi.org/10.1016/j.wasman.2008.07.004

Krygiel, E.; Nies, B. Green BIM: Successful sustainable design with building information modeling. Indianapolis, Indiana: John Wiley \& Sons, 2008.

Koutamanis, A. Building information modeling for construction and demolition waste minimization. In: Pacheco-Torgal, F.; Ding, Y.; Colangelo, F.; Tuladhar, R.; Koutamanis, A. Advances in construction and demolition waste recycling. Cambridge: Elsevier, 2020. p. 101-120. https://doi.org/10.1016/B978-0-12-819055-5.00007-3

Lage, I. M.; Abella, F. M.; Herrero, C. V.; Ordóñez, J. L. P. Estimation of the annual production and composition of C\&D Debris in Galicia (Spain). Waste Management, v. 30, no. 4, p. 636645, 2010. https://doi.org/10.1016/j.wasman.2009.11.016

Lau, H. H.; Whyte, A.; Law, P. L. Composition and characteristics of construction waste generated by Residential Housing Project. International Journal of Environmental Research, v. 2, no. 3, p. 261-268, 2008.

Liu, Z.; Osmani, M.; Demian, P.; Baldwin, A. N. The potential use of BIM to aid construction waste minimalisation. Proceedings of the CIB W78-W102 2011: International Conference, Sophia Antipolis, France, 2011. Available from: <https://dspace.lboro.ac.uk/2134/9198>. Accessed on: Apr. 28, 2021.

Liu, Z.; Osmani, M.; Demian, P.; Baldwin, A. N. A BIM-aided construction waste minimisation framework. Automation in Construction, v. 59, p.1-23, 2015. https://doi.org/10.1016/j.autcon.2015.07.020

Lu, W.; Webster, C.; Chen, K.; Zhang, X.; Chen. X. Computational Building Information Modelling for construction waste management: Moving from rhetoric to reality. Renewable and Sustainable Energy Reviews, v. 68, p.587-595, 2017a. https://doi.org/10.1016/j.rser.2016.10.029

Lu, Y.; Wu, Z.; Chang, R.; Li, Y. Building Information Modeling (BIM) for green buildings: A critical review and future directions. Automation in Construction, v. 83, p. 134-148, 2017b. https://doi.org/10.1016/j.autcon.2017.08.024

Masudi, A. F.; Che Hassan, C. R.; Mahmood, N. Z.; Mokhtar, S. N.; Sulaiman, N. M. Waste quantification models for estimation of construction and demolition waste generation: $\mathrm{A}$ review. International Journal of Global Environmental Issues, v. 12, no. 2/4, p. 269 281, 2012. https://doi.org/10.1504/IJGENVI.2012.049378

Mousa, M.; Luo, X.; McCabe, B. Utilizing BIM and carbon estimating methods for meaningful data representation. Procedia Engineering, v. 145, p.1242-1249, 2016. https://doi.org/10.1016/j.proeng.2016.04.160

Mueller, M. F.; Esmanioto, F.; Huber, N.; Loures, E. R. Canciglire Jr, O. A systematic literature review of interoperability in the green Building Information Modeling lifecycle. 
Journal of Cleaner Production, v. 223, p.397-412, 2019. https://doi.org/10.1016/ j.jclepro.2019.03.114

Nagalli, A.; Carvalho, K. Q. A model for estimating construction waste generation in masonry building. Waste and Resource Management, v. 172, p. 1-20, 2018. https://doi.org/10.1680/jwarm.18.00016

Nagalli, A.; Bertol, A. C.; Raffler, A., Santos, J. P. Analysis of between works characteristics and construction waste generation. Proceedings of the 14th International Waste Management and Landfill Symposium, Santa Margherita di Pula (CA), 2013.

Najjar, M.; Figueredo, K.; Palumbo, M.; Haddad, A. Integration of BIM and LCA: Evaluating the environmental impacts of building materials at an early stage of designing a typical office building. Journal of Building Engineering, v. 14, p. 115-126, 2016. https://doi.org/10.1016/j.jobe.2017.10.005

Novaes, M. V.; Mourão, C. A. M. A. Manual de gestão ambiental de resíduos sólidos na construção civil. Fortaleza: Cooperativa de Construção Civil do Estado do Ceará, 2008.

Osmani, M.; Glass, J.; Price, A. D. F. Architects' perspectives on construction waste reduction by design. Waste Management, v. 28, p.1147-1158, 2008. https://doi.org/10.1016/j.wasman.2007.05.011

Pinto, F. A. R. Resíduos sólidos industriais: caracterização e gestão - o caso do Estado do Ceará. Fortaleza: UFC, 2004. (Dissertação de mestrado).

Poon, C. S.; Ann, T. W.; Ng, L. H. On-site sorting of construction and demolition waste in Hong Kong. Resources, Conservation and Recycling, v. 32, no. 2, p. 157-172, 2001. https://doi.org/10.1016/S0921-3449(01)00052-0

Sacks, R.; Kaner, I.; Eastman, C. M.; Jeong, Y. The Rosewood experiment: Building Information Modeling and interoperability for architectural precast facades. Automation in Construction, $\quad$ v. 19 , no. $4, \quad$ p. $419-432, \quad 2010 . \quad$ https://doi.org/10.1016/ j.autcon.2009.11.012

Shi, Y.; Xu, J. BIM-based information system for econo-enviro-friendly end-of-life disposal of construction and demolition waste. Automation in Construction, v. 125, 103611, 2021. https://doi.org/10.1016/j.autcon.2021.103611

Solís-Guzmán, J.; Marrero, M.; Montes-Delgado, M. V.; Ramírez-de-Arellano, A. A Spanish model for quantification and management of construction waste. Waste Management, v. 29, no. 9, p. 2542-2548, 2009. https://doi.org/10.1016/j.wasman.2009.05.009

Won, J.; Cheng, J. C. P.; Lee, G. Quantification of construction waste prevented by BIMbased design validation: Case studies in South Korea. Waste Management, v. 49, p. 170180, 2016. https://doi.org/10.1016/j.wasman.2015.12.026

Won, J.; Cheng, J. C. Identifying potential opportunities of building information modeling for construction and demolition waste management and minimization. Automation in Construction, v. 79, p. 3-18, 2017. https://doi.org/10.1016/j.autcon.2017.02.002

Wu, Z.; Ann, T. W.; Shen, L.; Liu, G. Quantifying construction and demolition waste: An analytical review. Waste Management, v. 34, no. 9, p. 1683-1692, 2014. https://doi.org/ 10.1016/j.wasman.2014.05.010

Xu, J.; Shi, Y.; Xie, Y. Zhao, S. A BIM-Based construction and demolition waste information management system for greenhouse gas quantification and reduction. Journal of Cleaner Production, v. 229, p. 308-324, 2019. https://doi.org/10.1016/j.jclepro.2019.04.158 
Yost, P. A.; Halstead, J. M. A methodology for quantifying the volume of construction waste. Waste Management \& Research, v. 14, no. 5, p. 453-461, 1996. https://doi.org/10.1177/ $0734242 X 9601400504$

CC Attribution License, which permits unrestricted use, distribution, and reproduction in any medium, provided the original work is properly cited. 